Original Article

\title{
Health Promoting Lifestyle among Nurses of a Tertiary Level Hospital
}

*Pramila Baral ${ }^{1}$, Neeta Tamrakar ${ }^{2}$

${ }^{1}$ Lecturer, Department of Nursing, Kathmandu Medical College, Bhaktapur, Nepal

${ }^{2}$ Professor, Pokhara Campus, Institute of Medicine, Pokhara, Nepal

*Corresponding author:

Pramila Baral; baralpramilafiles@gmail.com

\begin{abstract}
Background: Lifestyle-related diseases are increasing worldwide representing $63 \%$ of all deaths globally. Healthpromoting behaviors among nurses may affect the quality of patient care and education. This study aims to identify the health-promoting lifestyle among nurses.

Methods: Descriptive, cross-sectional study design was used among 111 nurses working in Manipal Teaching Hospital, Pokhara from November 2016 to March 2017. A simple random sampling technique (lottery method) was applied using a self-administered structured standard tool, Health Promoting Lifestyle Profile II. The analysis was done using an independent t-test.

Results: The total Health-Promoting Lifestyle Profile II mean score was 137.66 \pm 19.18 . The highest mean score was in spiritual growth $(27.43 \pm 4.63)$ and lowest in physical activity $(17.03 \pm 4.88)$. A good health-promoting lifestyle was among $60.4 \%$ of the nurses. The significant difference in the mean score of total Health-Promoting Lifestyle Profile II was found in marital status ( $p=0.031)$ and educational qualification $(p=0.009)$. Likewise, the significant mean difference of interpersonal relations, nutrition and stress management was found with educational qualification $(p<0.05)$. The significant mean difference in nutrition was also found with marital status $(p=0.02)$. There was a significant mean difference in physical activity and spiritual growth with work experience $(p<0.05)$.

Conclusion: The spiritual aspect of health has been more focused by the nurses. Along with this, nurses need to put greater emphasis on physical activity and stress management for better health.

Keywords: Health Promotion; Lifestyle; Nurses, Nepal
\end{abstract}

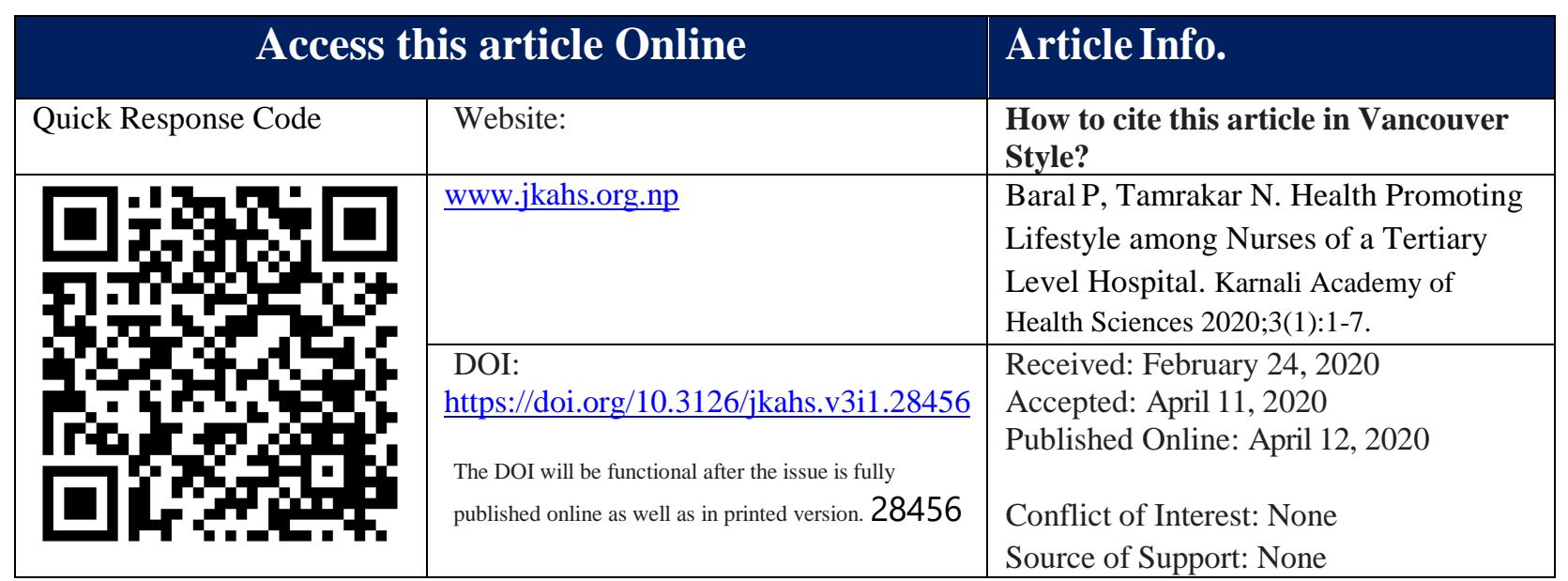




\section{INTRODUCTON}

Lifestyle of an individual influences healthpromoting behaviors. ${ }^{1}$ According to WHO 2012, $70-80 \%$ of deaths in developed and $40-50 \%$ in lessdeveloped countries are due to lifestyle associated diseases. $^{2}$

Nurses comprise the strongest health care force of 3.6 million and have the power to make difference in promoting health. Nurse can be a good example for being healthy by adopting healthy ways of living such as having balanced diet, managing stress, avoiding tobacco, getting immunizations and screenings etc. ${ }^{3}$

Studies have shown that nurses who smoke are less willing to promote healthy behaviors. ${ }^{4}$ A study conducted in America found that the majority of nurses were overweight, and self-reported health, diet and physical activity behaviors were low. ${ }^{5}$ While the study among Australian nurses revealed that the majority (94\%) indicated good, very good (45.5\%) and excellent (19.4\%) health. ${ }^{6}$ Likewise, a study conducted in Malaysia showed that nurses had a positive health-promoting lifestyle (HPL) with a score of $2.58 \pm 0.34$. The highest score was reported in spiritual growth $(2.92 \pm 0.43)$ and lowest in physical activity $(1.74 \pm 0.39){ }^{7}$

Nurses are caregivers, lifesavers and trusted resources. Hence, it is important for nurses to take care of their own health so as to deliver quality care. ${ }^{8}$ Nurses who are healthy and participate in healthy lifestyle behaviors are more likely to promote positive lifestyle of patients. Considering nurses as role model in health promotion and having professional knowledge regarding healthy lifestyle, little is known about nurses’ own lifestyle behaviors. In our context as well, these kinds of studies are limited and the health promoting lifestyle behaviors among nurses seem to be unexplored. Hence, this study aims to assess the health promoting lifestyle among nurses.

\section{MATERIALS AND METHODS}

Descriptive cross sectional research design was adopted to conduct the study from November 2016 to March 2017 among 111 nurses working in Manipal Teaching Hospital, Pokhara. Ethical approval was obtained from Research Committee of Pokhara Campus and Institutional Review Board of Tribhuvan University, Institute of Medicine. Written informed consent was taken from the participating nurses.

Sample size was calculated by using sample size calculation formula on the basis of mean score and standard deviation of total HPLP II score as 124.5 and 22.3 respectively from a study conducted in Iran and then formula for finite population was applied. ${ }^{9-11}$ Nurses with Proficiency Certificate Level or Bachelor level nursing qualification with work experience of more than 6 months were included in the study. A probability simple random sampling (Lottery method without replacement) was used. A self-administered structured questionnaire consisting of standard Health Promoting Lifestyle Profile II (HPL II) developed by Walker et al. was used which has six subscales. ${ }^{12}$

Mean was calculated for overall health promoting lifestyle and mean of the responses to subscale 
Baral et al. Health Promoting life style ......

items was calculated to obtain score of the six subscales. Statistical Package for Social Science (SPSS) Software Version 16 was used. Independent t-test was used for analysis.

\section{RESULTS}

The study was conducted among 111 nurses. The age of the nurses ranged from 19 to 40 years with mean age of $24.09 \pm 4.16$. The majority (65.8\%) of the nurses were between 19-24 age group. In respect to marital status, $61.3 \%$ of the nurses were unmarried and $88.3 \%$ of the nurses were living with family. (Table 1)

Table 1. Distribution of Socio-demographic Characteristics of Nurses $(n=111)$

\begin{tabular}{|c|c|c|}
\hline Variables & Number & Percentage \\
\hline \multicolumn{3}{|l|}{ Age (in years) } \\
\hline $19-24$ & 73 & 65.8 \\
\hline $25-40$ & 38 & 34.2 \\
\hline \multicolumn{3}{|l|}{$\begin{array}{l}\text { Mean age } \pm \text { S.D.in } \\
\text { years }=24.09 \pm 4.16\end{array}$} \\
\hline \multicolumn{3}{|l|}{ Marital status } \\
\hline Unmarried & 68 & 61.3 \\
\hline Married & 43 & 38.7 \\
\hline \multicolumn{3}{|l|}{ Living arrangements } \\
\hline With family & 98 & 88.3 \\
\hline Without family & 13 & 11.7 \\
\hline
\end{tabular}

Table 2. Distribution of Job related

Characteristics of Nurses $(n=111)$

\begin{tabular}{|c|c|c|}
\hline Variables & $\mathbf{N}$ & Percentage \\
\hline $\begin{array}{l}\text { Educational } \\
\text { qualification }\end{array}$ & & \\
\hline Undergraduate & 95 & 85.6 \\
\hline Graduate & 16 & 14.4 \\
\hline $\begin{array}{l}\text { Working } \\
\text { experience }\end{array}$ & & \\
\hline
\end{tabular}

\begin{tabular}{|c|c|c|}
\hline$<3$ years & 69 & 62.2 \\
\hline $\mathbf{3}$ years & 42 & 37.8 \\
\hline $\begin{array}{c}\text { Present working } \\
\text { ward/unit }\end{array}$ & 59 & 53.2 \\
\hline General & 32 & 28.8 \\
\hline Critical & 20 & 18.0 \\
\hline Others & & \\
\hline
\end{tabular}

The job related characteristics of the nurses are given in Table 2. Majority (85.6\%) of nurses were undergraduate. With regard to work experience, $62.2 \%$ of the nurses had experience of less than three years. More than half (53.2\%) of the nurses were currently working in general ward.

Note: undergraduate and graduate nurses included those who have passed PCL and bachelor's degree in nursing education respectively.

\section{Table 3. Distribution of Health related}

\section{Characteristics of Nurses}

\begin{tabular}{|l|r|r|}
\hline \multicolumn{1}{|c|}{ Variables } & Number & Percentage \\
\hline $\begin{array}{l}\text { Perceived } \\
\text { current health } \\
\text { problem* }\end{array}$ & & \\
\hline Yes & 21 & 18.9 \\
\hline Musculoskeletal & 11 & 9.9 \\
\hline Gastrointestinal & 4 & 3.6 \\
\hline Endocrinal & 3 & 2.7 \\
\hline Others & 6 & 2.7 \\
\hline No & 90 & 81.1 \\
\hline Rating of & & \\
\hline current health & & 9.9 \\
\hline Excellent & 11 & 72.1 \\
\hline Good & 80 & 18.0 \\
\hline Fair & 20 & \\
\hline Multiple Response Question & \\
\hline
\end{tabular}

*Multiple Response Question 
Health related characteristics of nurses are shown in Table 3. Approximately one fifth (18.9\%) of the nurses perceived that they had health problem. The most common health problem was related to musculoskeletal system (9.9\%). In respect to rating of their current health, $72.1 \%$ of the nurses rated their current health as being good whereas, only 9.9\% rated their current health to be excellent.

Table 4. Distribution of Level of Health Promoting Lifestyle among Nurses

\begin{tabular}{|c|c|c|}
\hline $\begin{array}{c}\text { Health Promoting } \\
\text { Lifestyle Level }\end{array}$ & Number & Percentage \\
\hline Excellent (172- & 5 & 4.5 \\
\hline 208) & 67 & 60.4 \\
\hline Good (132-171) & 37 & 33.3 \\
\hline General (92-131) & 2 & 1.8 \\
\hline Poor (52-91) & & \\
\hline $\begin{array}{l}\text { Total } \\
100\end{array}$ & \multicolumn{2}{|c|}{111} \\
\hline
\end{tabular}

Table 4 depicts that $60.4 \%$ of the nurses had good and only $1.8 \%$ of the nurses had poor health promoting lifestyle.

Table 5. Mean and Standard Deviation of Each Subscale of HPLP II among Nurse

\begin{tabular}{|l|r|}
\hline HPLP II Subscales & Mean \pm SD \\
\hline Spiritual growth & $27.43 \pm 4.63$ \\
\hline Interpersonal relations & $25.56 \pm 3.81$ \\
\hline Health responsibility & $23.74 \pm 4.78$ \\
\hline Nutrition & $23.37 \pm 4.42$ \\
\hline Stress management & $20.50 \pm 3.96$ \\
\hline Physical activity & $17.03 \pm 4.88$ \\
\hline \begin{tabular}{l|r} 
Minimum HPLP II \\
score
\end{tabular} & 88.00 \\
\hline $\begin{array}{l}\text { Maximum HPLP } \quad \text { II } \\
\text { score }\end{array}$ & 192.00 \\
\hline Total HPLP II score & $137.66 \pm 19.18$ \\
\hline
\end{tabular}

Table 5 depicts that among the six subscales, the mean of spiritual growth was highest $(27.43 \pm 4.63)$ and physical activity was lowest $(17.03 \pm 4.88)$. Likewise, total HPLP II score was $137.66 \pm$ 19.18.

Table 6. Difference in Socio- demographic and Job Related Variables with Total HPLP II Scores

\begin{tabular}{|c|c|c|c|c|c|}
\hline Variables & Number & Mean Score & $\begin{array}{c}\text { SE } \\
\text { Mean }\end{array}$ & $\begin{array}{c}t- \\
\text { value }\end{array}$ & $p$-value \\
\hline \multicolumn{6}{|l|}{ Age (in years) } \\
\hline $19-24$ & 73 & 136.83 & 2.09 & -0.63 & 0.530 \\
\hline 25- 40 & 38 & 139.26 & 3.50 & & \\
\hline \multicolumn{6}{|l|}{ Marital status } \\
\hline Unmarried & 68 & 134.55 & 2.02 & 2.18 & 0.031 \\
\hline Married & 43 & 142.58 & 3.33 & & \\
\hline Living arrangements & & & & & \\
\hline
\end{tabular}


Baral et al. Health Promoting life style ......

\begin{tabular}{|l|l|l|l|l|r|}
\hline With family & 98 & 137.89 & 1.94 & 0.34 & 0.729 \\
\hline Without family & 13 & 135.92 & 5.33 & & \\
\hline $\begin{array}{l}\text { Educational } \\
\text { qualification }\end{array}$ & & & & & \\
\hline Undergraduate & 95 & 135.73 & 1.84 & -2.65 & 0.009 \\
\hline Graduate & 16 & 149.12 & 5.63 & & 0.065 \\
\hline Working experience & & & & -1.86 & \\
\hline$<$ 3 years & 69 & 135.04 & 2.03 & & \\
\hline$\geq 3$ years & 42 & 141.97 & 3.39 & & \\
\hline
\end{tabular}

SE: Standard Error $\quad p$ value significant at $<0.05$

Table 6 depicts that there was significant difference in marital status $(p=0.031)$ and educational qualification ( $p=0.009)$ with total HPLP II scores. However the highest mean was observed with increasing age (139.26), education (149.12), work experience (141.97), among married (142.58) and those living with family.

\section{DISCUSSION}

The finding of this study shows that mean of spiritual growth is highest (27.43) and physical activity is lowest (17.03). The high value of spiritual growth may be due to the trends driving interest in spirituality. ${ }^{13}$ Lowest score in physical activity might be due to the factors like lack of time, facilities having inconvenient schedule and exercise not fitting around duty schedules. ${ }^{14}$ This corresponds to the findings of previous studies. ${ }^{15-18}$

The present study analyzed that the total mean score on HPLP II was (137.66 \pm 19.18$)$. The finding is slightly similar with the study conducted in Iran. ${ }^{15}$ The present study depicts that there is significant difference in marital status $(p=0.031)$ with total HPLP II scores. Similar result was obtained in a study conducted in Turkey. ${ }^{2}$ The result of the present study shows that there is significant difference between educational qualification and total HPLP II scores. This finding is in contrast to the study conducted in Iran. ${ }^{10,16}$

The present study shows that the difference in educational qualification and interpersonal relations subscale is significant $(p=0.01)$. This is opposite with the results of study conducted in Taiwan which indicated that the difference in work experience and interpersonal relations was significant. ${ }^{18}$ The present study represents that the difference in nutrition subscale with marital status is significant $(p=0.02)$. This might be due to the reason that married individuals have intake consistent with the dietary guidelines and that they may have impact in food preparation, preferences, income, amount and varieties of food, etc. ${ }^{19}$ The finding of this study is similar with findings of study conducted in Iran. ${ }^{20}$

The findings of this study shows that there is no statistical significance difference in health responsibility with respect to socio demographic and job related variables. While the study carried in Taiwan showed significant difference in work experience with health responsibility. ${ }^{18}$ This might be due to cultural differences.

There was statistical significant difference in physical activity with work experience $(p=0.038)$ in present study. In contrary Lee found that nurses 
( $\geq 35$ years) with more experience were less likely to maintain healthy weight indicating low physical activity. ${ }^{21}$

The results of this study illustrates difference in stress management subscale for educational qualification ( $p=0.005)$. The reason may lie in the fact that schools and colleges play a vital role in stress management by assuring a healthy learning environment, providing services for stress reduction, enhancing student's knowledge and skills for coping with stress, and coordinating activities with families and communities. However the study done in Pennsylvania showed significant differences in stress management with age of nurses. $^{22}$

The present study depicts that there is statistical significant difference in work experience with spiritual growth. Though statistically insignificant, this study shows higher mean score of spiritual growth among nurses living with family. This might be due to the fact that family life increases spirituality by growing together and supporting each other. ${ }^{23}$ The similar result was obtained in previous study. ${ }^{1}$

\section{CONCLUSIONS}

The health promoting behaviors are more among nurses who are married and graduates. Amongst the health promoting behaviors, spiritual aspect has been more focused by the nurses. In addition, lifestyle modifications regarding increasing physical activities and stress management need to be emphasized for promoting better health.

\section{Acknowledgement}

We would like to thank all the nurses who participated in the study.

\section{REFERENCES}

1. Al-Qahtani MF. Health-promoting lifestyle behaviors among nurses in private hospitals in AlKhobar, Saudi Arabia. J Egypt Public Health Assoc. 2015; 90(1): 29-34. PubMed

2. Kirag N, Ocaktan EM. Analysis of health promoting lifestyle behaviors and associated factor among nurses at a university hospital in Turkey. Saudi Med J. 2013; 34(10):1062-1067. PubMed P

3. American Nurses Association. Healthy Nurse Healthy Nation. 2017. [Accessed $6^{\text {th }}$

November,2016]

Full Text

4. Lenz BK. Beliefs, knowledge, and self-efficacy of nursing students regarding tobacco cessation. Am J Prev Med.2008; 35(6): 494-500. PubMed

5. Zapka JM, Lemon SC, Magner RP, Hale J. Lifestyle behaviours and weight among hospitalbased nurses. J Nurs Manag.2009; 17(7), 853-860. PubMed | Google Scholar

6. Perry L, Gallagher R, Duffield C. The health and health behaviours of Australian metropolitan nurses: an exploratory study. BMC Nurs.2015; 14(1): 1-11.

Full Text

7. Geok S, Yusof A, Lam S, Japar S, Leong O, Fauzee M. Physical activity and health-promoting lifestyle of student nurses in Malaysia. J Biosci Med.2015;2(3) :78-87.

Full Text

8. Reed D. Healthy eating for healthy nurses: Nutrition basics to promote health for nurses and patients. Online J Issues in Nurs. 2014; 19(3):7. [Accessed $6^{\text {th }}$ November, 2016]. Available from Google Scholar | PubMed

9. Walters SJ. Sample size and power estimation for studies with health related quality of life outcomes. Health and Quality of life Outcome.2004; 2(26). Full Text

10. Nejat K, Abedi H. Evaluation of health promotion activities in nurses. J Novel Applied Sci.2015; 4 (6): 715-720. [Accessed15 ${ }^{\text {th }}$

November,2016]Retrieved from Full Text

11. Panta PP. Biostatistics. Kathmandu, Nepal: Vidyarthi Pustak Bhandar;2012.

12. Walker, Susan N, Sechrist, Karen R, Pender, Nola J. Health promotion model-instruments to measure health promoting lifestyle: Health-promoting lifestyle profile [HPLP II] (Adult version). J Nurs Res.1995; 22(7): 796-811. [Accessed 6 ${ }^{\text {th }}$

November,2016]. Available from https://deepblue.lib.umich.edu/handle/2027.42/853 49

13. Barlow A. Spirituality in nursing.2015. [Accessed $15^{\text {th }}$ February,2017] Available from on 3/3/2017 [Link] 
14. Blake H, Stanulewicz N, Mcgill F. Predictors of physical activity and barriers to exercise in nursing and medical students. J Adv Nurs.2016; 00(0): 000-000. [Accessed 6 ${ }^{\text {th }}$ December,2016] PubMed

15. Kalroozi F, Pishgooie AH, Taheriyan A. Healthpromoting behaviours in employed nurses in selected military hospitals in Iran. J Health Promot Management. 2015; 4 (2): 7-1. Full Text

16. Shirazi FM, Forouhari S, Rostambeigy P, Ghaemi SZ, Roshandel A, Ashtary F. The relationship between work-family balance and health promoting lifestyles in employed women. Int $\mathrm{J}$ Current Life Sci.2015;5 (3): 405-408 Google Scholar | Full Text

17. Edrisi AM, Khademloo M, Ghorbani AA, Gooran F, Khalili-Azandehi H, Bahrami B,et al. Self report of health promoting behaviors of nurses working in the educational hospitals. J Mazand Univ Med Sci.2013; 23(105): 52-59. Full Text

18. Tsai YC, Liu CH. Factors and symptoms associated with work stress and health-promoting lifestyles among hospital staff: a pilot study in Taiwan. BMC Health Serv. Res.2012; 12, 199. PubMed

19. Roos E, Lahelma E, Virtanen M, Prattala R, Pietinen P. Gender, socioeconomic status and family status as determinants of food behavior. Social Sci Med.2008; 46 (12): 15191529.

\section{PubMed}

20. Hosseini M, Ashktorab T, Taghdisi MH, Vardanjani AE, Rafiei H. Health-promoting behaviors and their association with certain demographic characteristics of nursing students of Tehran City in 2013. Global J Health Sci.2015;7(2): 264-272. [Accessed 23rd November,2016]Available from https://www.ncbi.nlm.nih.gov/pubmed/25716384. doi: 10.5539/gjhs.v7n2p264 PubMed

21. Lee H. Barriers and facilitators to engaging in health promoting behaviors among nurses in an urban setting: a mixed-method study. Johns Hopkins University.2013

Google Scholar

22. Thacker K, Haas SD, Brancato V, Flay C, Greenawald D. An investigation into the healthpromoting lifestyle practices of registered nurses. Am J Nurs.2016; 116(4): 24-30. [Accessed 21 ${ }^{\text {st }}$ February,2017]Available from https://www.ncbi.nlm.nih.gov/pubmed/26974744

23. Gregory P. Family Spirituality: So What? Who Cares? \& What's In It For You?2015. Retrieved from PubMed

24. http://www.patheos.com/blogs/faithonthecouch/20 15/07/family-spirituality-so-what-who-careswhats-in-it-for-you on 2/2/2017

\section{Full Text}

